\title{
Performance Evaluation of Institutional Integration Forms in Real and Financial Sector Companies
}

\author{
R.M. Kundukchyan
}

R.R. Gaizatullin

\section{Z.N. Zappartova}

N.V. Antonova

Doi:10.5901/mjss.2014.v5n12p59

\author{
Kazan Federal University, Kazan, 420008, Russia
}

\begin{abstract}
The article analyses the factors which provide efficient interaction between real and financial regional economy in the frame of integrate holding structure (IHS), where bank is the financial center. The authors offer performance evaluation methods for institutional integration forms. They prove that government regulatory control is a prerequisite to implement the bank strategy. This control includes creation of institutional environment on banking and financial service market, creation of a government programme to provide minimum bank and financial services, adjustment of the main offices of the Bank of Russia in accordance with the district structure.
\end{abstract}

Keywords: integrate holding structures, bank sector, lending agencies, real economy, government control, integrate structures performance rate.

\section{Introduction}

According to the Central Bank of the Russian Federation early in December 2013 the total assets of Russian banks equaled 47.6 trillion rubles. A recent projection, prepared by the RF Ministry of Finances, concluded that assets of banks are likely to double by 2020 and be equivalent to 104 trillion rubles, and insurance rate is expected to grow up to $5 \%$ of GDP. If the figures are to reach the expected level, annual credit market augmentation will be around 10-15\% [1]. But then, the analysis shows that the banking system is not involved in the state undertakings aimed at stimulating economic growth. Despite the expansion of big banks to regions, there appeared an opposing tendency to improve regional branches in order to reduce costs. It had a negative impact on banking quality. Unequal access of regional banks to the recourses is caused by inefficient policy of the Bank of Russia and other state administration bodies in developing fair competition, both within banking industry and between lending agencies and the stock market.

High growth rate of credit operations is accompanied by accumulation of credit risk in banking sector. Its probability increases as the economic situation in certain spheres of non-financial sector deteriorates, the financial situation of the borrowers goes down accordingly, so does their capability of catering for their debts before the landing agencies $[4 ; 7 ; 8$; 11]. This implies that financial and banking services can play quite an insignificant role in the reproduction process of non-financial sector. This fact also points to inequality of their distribution by regions [2].

Globalization of economic space and intensive development of global economic cooperation and interbank communication removed restrictions from free migration of capital. Competitive activity intensified, both on the world and national financial market. These factors justify theoretic methodical approaches to the problem of development and implementation of an efficient strategy for interaction between banking and real sector within the system of government control. Growing economic polarization in Russia keeps current the problem of creating adaptive tools and approaches to provide competitive ability of multidivisional banks on the local banking market. It necessitates new forms of communication with the regional non financial entities. Conditioned upon efficient federal and regional government control as the major factor which helps maintain national competitiveness, it is possible to eliminate disequilibria in banking, foster transformation of savings into investments, bridge the gap with real economy and therefore stabilize national macroeconomic performance. Presence of these facts establishes a need to investigate integration processes in real and financial sectors of economy, as well as develop methods to assess the performance of integrate structures.

Banking theory was investigated by a number of foreign scholars including: B. Carney, C.H. Douglas, H. Grubel, S. O'Donnell, E. Ballarin, Derek F. Channon, P. Rose, J. Sinkey, H. Derig, etc. 


\section{Methodology}

System of relations between real and financial sectors requires a fundamental analysis. Therefore, we will need a number of specific complementary methods and modes, which make it possible to reveal in full the essence of economic relations on banking and financial service market. In the view of this, in the course of the analysis we used methods of dialectic and system analysis, methods of scientific abstraction and comparison of statistical inquiries, economic and mathematical methods to estimate the mean, methods to classify economic indexes.

The study is based on the information provided by the RF Government Statistics Federal Agencies and their local offices, the RF Ministry of Finances, the RF Central Bank, Russian Bankers' Association.

Institutional integration forms for real and financial sectors in today's economy are interpreted as a set of contracts concerning tangible and conceptual objects (title of ownership for monetary capital) which can be realized as a right for income (profit or dividend). Institutionalization of the real and financial companies integration process provides a mutually advantageous exchange of legal powers against the background of various transactions coexisting between manufacturing enterprises, credit and finance market entities. Their behavior is to be restricted by a number of limits set by the institution, and defined by a system of incentives and control on the part of the state. Institutional integration forms for real and financial sectors of Russian economy are of contradictory nature. They comprise a complex system of relations between property and conflicting economic interests: on the one hand, substantial predominance of bank capital growth over productive industry growth rate expands the demand for capital as a source of investments into non-financial economy. It has an immediate effect on real capital proprietors' interest. On the other hand, bank capital accumulation in the growing number of financial instruments leads to its separation from the real sector. Autonomation tendency implies that bank entities act in their interests by means of income and expenditures optimization.

\section{Result}

In the modern context the most efficient institutional form of real and financial regional sectors integration is an integrated holding entity (IHE). Our definition for this organization is "a group of legal entities in partnership with a lending agency (or lending agencies) together with companies producing goods and services". The integrating factor is either dominant participation in the authorized capital, or contracts between its members, or force of economic dependence [11, 15].

For interaction between banks and non-financial establishments within the IHE model, where bank stands as the financial center, the efficiency factor is group communication efficiency. It aims to improve synergetic capabilities associated with all forms of capital integration, and reinforce the cooperation in order to implement the mission. Bank policy implementation is conditional upon regulatory control measures. Among the most relevant measures for the Russian Federation policy at the national level are to:

1. Develop institutional environment of banking and financial services, including legislative development, providing membership expansion of the bank holding as an IHE prototype and support their legal non banking activities.

2. Create government program of providing minimum quality banking and financial services.

3. Combine administrative and policy regional measures to adjust the structure of the Bank of Russia main offices in accordance with the district structure.

4. At the regional level it is necessary to: create equal terms for regional and strategic banks; maintain competitive landscape, including prohibition of illegitimate preferences to certain lending agencies.

5. Develop institutions to guarantee cooperation between IHE members (non commercial organizations, such as Bankers' association of the Republic of Tatarstan (RT), Chamber of Commerce and Industry, etc.), as a way to foster contacts with retail and corporate customers.

6. Expand lending agencies' funding base; draft arrangements to increase information transparency, and update methodological support for antimonopoly regulation of this market segment.

7. Mobilize home resources and guarantees of regional authorities in order to create a fund to discharge mortgages from local lending agencies and bank subsidiaries of other regions.

8. Foster activity of financial intermediaries - credit unions, microfinance organizations, collection agencies, loan brokers, retail agents; involve investors from other regions by weakening influence of restrictions, etc.

Regional regulatory control actions at the setting of macroeconomic conjuncture decrease (its implementation mechanism you can see in Fig.1) is an essential element of anti-cyclical measures system. 


\begin{tabular}{|c|c|c|c|c|}
\hline Problem & \multicolumn{2}{|c|}{ Credibility gap } & \multicolumn{2}{c|}{ Credit market freez } \\
\hline $\begin{array}{c}\text { Forms of emerging } \\
\text { problem }\end{array}$ & $\begin{array}{c}\text { Decline of confidence in banks by } \\
\text { general public }\end{array}$ & $\begin{array}{c}\text { Banks' non-confidence in } \\
\text { contra parties }\end{array}$ & $\begin{array}{c}\text { Inter-bank market } \\
\text { shrinkage }\end{array}$ & $\begin{array}{c}\text { Under capitalization of } \\
\text { banks }\end{array}$ \\
\hline \multirow{2}{*}{ Actions } & $\begin{array}{c}\text { Increase in insured investments } \\
\text { compensation }\end{array}$ & $\begin{array}{c}\text { Warranties under } \\
\text { commitment }\end{array}$ & $\begin{array}{c}\text { Purchase/support } \\
\text { assets }\end{array}$ & $\begin{array}{c}\text { State capital infusion } \\
\text { into banks }\end{array}$ \\
\cline { 2 - 5 } & Federal control & \multicolumn{2}{|c|}{ Federal and regional control } \\
\hline
\end{tabular}

Fig.1. Mechanism of regulatory control over banking services market in the modern context

The leading RT regional banks, whose rating fragment you can see in table 1, use various forms of cooperation with non financial entities and regional authorities. So, for example the shareholders of JSCo "Ak Bars" bank are LLC "IKS LUTH" (19.96\% of the nominal capital), LLC "Investments and Consulting" (16.92\%), JSCo "Ak Bars" holding company (13\%) and other companies whose promoters and shareholders are regional authorities.

The shareholder of JSCo "Akibank" is JSCo "Generiruiushaia compania" (6.2\%); the shareholder of JSCo "AIKB Tatfondbank" is JSCo "Tatagrolizing" (24\%); the shareholder of joint stock bank "Devon credit" is JSCo "Zenit" bank (97.3\%). Moreover, the latter purchased the controlling interest of JSCo "Tatneft" (the sixth biggest RF Oil Company, $35.9 \%$ of its shares belong to the RT Government), which remains beneficiary to institutions within the bank.

Table 1: Fragment of bank rating on 1.01 .2013 by assets value

\begin{tabular}{|r|l|c|c|c|c|}
\hline № & Bank & $\begin{array}{c}\text { Net assets on 01.01.13, } \\
\text { mln. rubles }\end{array}$ & $\begin{array}{c}\text { Net assets on } \\
01.01 .08, \text { mln. rubles }\end{array}$ & $\begin{array}{c}\text { Annual } \\
\text { change, } \%\end{array}$ & $\begin{array}{c}\text { № in the } \\
\text { national rating }\end{array}$ \\
\hline 1 & JSCo "Ak Bars" bank & 210774 & 153436 & 37,37 & 20 \\
\hline 2 & JSCo "AlKB Tatfondbank & 43777 & 42039 & 4,13 & 67 \\
\hline 3 & Joint stock bank "Devon credit" (JSC0) & 22026 & 18234 & 20,8 & 105 \\
\hline 4 & JSCo "AKIBANK" & 15615 & 12336 & 26,58 & 126 \\
\hline 5 & JSCB "Energobank" (JSCo) & 10085 & 8171 & 23,42 & 172 \\
\hline 6 & JSCo "Kazansky" bank & 10075 & 9426 & 6,88 & 173 \\
\hline 7 & $\begin{array}{l}\text { JSCO joint stock company "Spurt" } \\
\text { bank }\end{array}$ & 10038 & 9124 & 10,01 & 174 \\
\hline 8 & JSCB «BTA Kazan" (JSCo) & 9503 & 8899 & 6,79 & 179 \\
\hline 9 & JSCo commercial bank "Intechbank" & 5805 & 5356 & 8,4 & 244 \\
\hline 10 & LLC MCB "Avers" & 5203 & 2663 & 95,37 & 272 \\
\hline
\end{tabular}

Therefore, major role of regional authorities, and lack of IHE, where the bank acts as the financial center, are peculiar to the RT banking services market.

Typically, credit resource markets are characterized by highly asymmetric information. It provokes real sector entities' lack of finance, which restricts systemic changes in the performance of manufacturing enterprise. What is more, banks encounter difficulties in building balanced lending portfolio, which under the conditions of economic instability leads to decline in their efficiency. As a result, profit of real and financial sector entities decreases, the state receives less profit tax than due, and the budgetary efficiency of the regional social economy weakens. On the one hand, banking business activation through consolidation with industrial capital will reduce the risk factor when investing financial resources, and therefore will lead to profit markup by running down past-due accounts $[13,16]$. On the other hand it will make the financial resources accessible to enterprises, and therefore lower dead expenses (loan interest overpayment) and consequently increase the profit of financial organizations. The resulting budgetary efficiency can be calculated as follows:

If budget $=D_{\text {reg }} \sum\left(\mathrm{k}_{1} * P p_{\text {bank }}+\mathrm{k}_{2} * \mathrm{P}_{\text {company }}\right)^{\mathrm{i}}$,

where: Dreg - is the regional profit tax constituent, fraction

$\mathrm{k}_{1}$ - is the scaling factor, which describes increment in regional banking sector profit resulting from consolidation of bank and industrial capital, by years when consolidation of capital was put into effect;

$\mathrm{k}_{2}$ - is the scaling factor which describes increment in regional industrial sector profit resulting from consolidation of bank and industrial capital, by years when consolidation of capital was put into effect; of rubles;

$\mathrm{Pp}_{\text {bank }}$ - is regional banking sector profit in the years without consolidation of bank and industrial capital, thousand

Ppcompany - is the regional industrial sector profit in the years without consolidation of bank and industrial capital, thousand of rubles; 
$\mathrm{i}(1 ; n)$ - years when consolidation of bank and industrial capital was put into effect.

The RT companies' revenue trends following condensation of bank and industrial capital were assessed by three possible outcomes: optimistic (maximum possible budget effect), most probable ( $40 \%$ of the maximum possible budge effect) and pessimistic ( $20 \%$ of the maximum possible budge effect). The results of computations are represented in table 2.

Table 2: The RT processing factories and bank sector revenue trends in 2014-2018 (by possible outcomes), mln. rubles. (forecast)

\begin{tabular}{|l|c|c|c|c|c|}
\hline Outcome & $\mathbf{2 0 1 4}$ & $\mathbf{2 0 1 5}$ & $\mathbf{2 0 1 6}$ & $\mathbf{2 0 1 7}$ & $\mathbf{2 0 1 8}$ \\
\hline Pessimistic & $-2836,53$ & $-620,97$ & 125,72 & 132,01 & 138,61 \\
\hline most probable & $-1469,75$ & 41,78 & 616,17 & 677,79 & 759,12 \\
\hline Optimistic & 593,80 & 623,49 & 685,84 & 823,01 & 987,61 \\
\hline
\end{tabular}

From the forecast above you can see that even with the most probable outcome implementation, the joint sector will pass into profit. Regional trends in profit tax throughout the forecast period are represented in Fig.2.

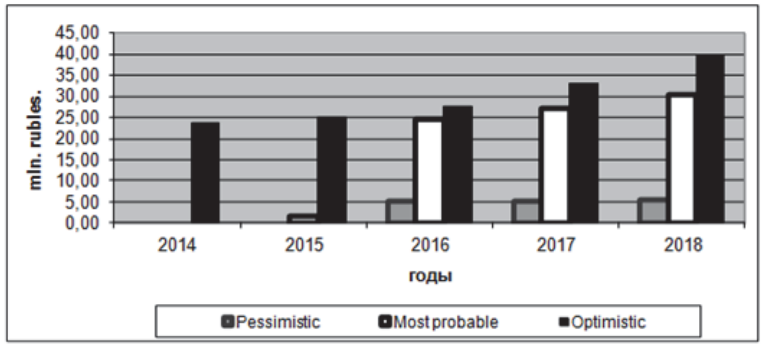

Fig. 2. Trends in regional profit tax proceeds in the RT in 2014-2018, mln. rubles. (forecast)

\section{Conclusion}

Computations show that if the consolidation of bank and industrial capital does not take place, the finance result of the above mentioned sectors will remain negative till 2017. Therefore, further development of integration processes involving real and bank sector entities, as well as involving regional banks into integration processes appears well-grounded.

\section{References}

The RF banking sector development trends overview (end of 2012 - beginning of 2013). [web page]. Available: http://http://www.veb.ru/common/upload/ files/veb/analytics/fld/20130704 banks.pdf

Official site of the Central Bank of the Russian Federation [web page]. Available: http://www.cbr.ru.

Allen F., Santomero A. The Theory of Financial Intermediation // Journal of Banking and Finance.1997.Vol. 21. pp. 1461-1485.

Cornett M., Tehranian H., Changes in Corporate Performance Associated with Bank Acquisitions", Journal of Financial Economics, 1992, Vol. 31, pp. 211234.

Safiullin L.N., Gafurov I.R., Shaidullin R.N., Safiullin N.Z. Socio-economic development of the region and its historical and cultural heritage. Life Science Journal 2014; 11(6s): 400-404.

Diamond D.W., Dybvig P.H. Bank Runs, Deposit Insurance, and Liquidity // Journal of Political Economy. 1983. Vol. 91. No 3. P. 401-419.

Askhatova L.I., Fatkhiev A.M., Safiullin L.N. and Safiullina A.M. Competitive Strategies Formation in High Technology Enterprise // World Applied Sciences Journal, 27(13), 2013, pp. 20-23.

Ajupov A.A. Risk-Engineering, As an Element of Financial Engineering in the Market of Innovative Financial Products, 27(13), 2013, pp. 5-9.

Eichengreen B., Rose A. Staying afloat when the wind shifts: External factors and emerging-market banking crises, NBER Working paper 6370, 1998.

Kundakchyan R.M., Zulfakarova L.F. Current issues of optimal capital structure based on forecasting financial performance of the company. Life Science Journal 2014; 11(6s): 368-371.

Ajupov A. Definitions of concepts scope and interaction of risk-engineering on the financial market. Life Science Journal 2014; 11(6s): 337-340.

Glebova I.S., Sadyrtdinov R. and Rodnyansky D. Impact Analysis of Investment Attractiveness of the Republic of Tatarstan on Fixed Investments of its Leading Companies // World Applied Sciences Journal 26 (7): 911-916, 2013.

Kramin M.V., Safiullin L.N., Kramin T.V., Timiryasova A.V. Drivers of economic growth and investment attractiveness of Russian regions. Life Science Journal 2014; 11(6s): $526-530$

Ennis H.M., Keister T. Bank Runs and Institutions: The Perils of Intervention // American Economic Review. 2009. Vol. 99. No 4. P. $1588-1607$.

Fakhrutdinova, E., Safina, L., Kolesnikova, J., Fedor, Mikhailov. Quality formation of working life of the youth// World Applied Sciences Journal. Volume 27, Issue 13, 2013, Pages 87-91.

Frederick C. Schadrack, Leon Korobow The basic elements of bank supervision. Lectures, At Fairfield University Fairitld, Connecticut, Federal Reserve Bank of New York, July 1993. 